\title{
ANALISIS REGRESI MULTIVARIAT BERDASARKAN FAKTOR-FAKTOR YANG MEMPENGARUHI DERAJAT KESEHATAN DI PROVINSI MALUKU
}

\author{
Salmon N. Aulele ${ }^{1}$, A. Z. Wattimena ${ }^{2}$, Christy Tahya ${ }^{3}$ \\ 1, 2,3 Jurusan Matematika Fakultas Matematika dan Ilmu Pengetahuan Alam, Universitas Pattimura \\ Jalan Ir. M. Putuhena, Kampus Unpatti, Poka, Ambon, Indonesia \\ e-mail: ${ }^{1}$ salmon.aulele@yahoo.com
}

\begin{abstract}
Abstrak
Kesejahteraan merupakan tujuan utama pembangunan sebuah negara. Salah satu aspek penting untuk mengukur tingkat kesejahteraan adalah kualitas fisik penduduk, yang dapat dilihat dari derajat kesehatan penduduk. Derajat kesehatan suatu daerah dapat dipengaruhi oleh banyak variabel. Model regresi multivariat adalah model regresi dengan lebih dari satu variabel respon yang saling berkorelasi dan satu atau lebih variabel prediktor. Tujuan dari penelitian ini adalah untuk mengetahui gambaran kesehatan masyarakat di Provinsi Maluku serta menentukan faktor-faktor apa saja yang mempengaruhi angka kematian bayi, angka harapan hidup, dan status gizi buruk di Provinsi Maluku dengan menggunakan regresi multivariat. Hasil penelitian menunjukan bahwa persentase angka kematian bayi tertinggi yaitu di kabupaten Maluku Tenggara Barat, persentase angka harapan hidup tertinggi yaitu di Kota Ambon dan untuk persentase Status Gizi Buruk tertinggi di kabupaten Kepulauan Aru. Sedangkan faktor-faktor yang mempengaruhi angka kematian bayi, angka harapan hidup, dan status gizi buruk di Provinsi Maluku dengan menggunakan regresi multivariat yaitu persentase rumah tangga yang menggunakan jamban dengan tangki septik $\left(X_{1}\right)$, persentase peran aktif masyarakat dalam posyandu $\left(X_{3}\right)$, persentase rata-rata lamanya bayi di beri ASI ekslusif $\left(\mathrm{X}_{4}\right)$, persentase persalinan yang dilakukan oleh tenaga medis $\left(\mathrm{X}_{5}\right)$, persentase imunisasi lengkap $\left(\mathrm{X}_{6}\right)$, persentase kepadatan penduduk $\left(\mathrm{X}_{7}\right)$ dan model dapat menjelaskan informasi data sebesar $99,4 \%$.
\end{abstract}

Kata Kunci: Angka harapan hidup, angka kematian bayi, model regresi multivariat, status gizi buruk

\section{MULTIVARIATE REGRESSION ANALYSIS BASED ON FACTORS AFFECTING HEALTH STATUS IN MALUKU PROVINCE}

\begin{abstract}
Prosperity is the main objective of development of a country. One important aspect to measure the level of well-being is the physical quality of the population that can be seen on the health status of the population. Health status of an area can be affected by many variables. Multivariate regression model is a regression model with more than one response variable cross-correlated and one or more predictor variables. The purpose of this research is to find a picture of public health in Maluku Province and determine the factors that influence infant mortality, life expectancy, and poor nutritional status in Maluku province using multivariate regression. The results showed that the percentage of the highest infant mortality rate in West Southeast Maluku district, the percentage of the highest life expectancy in the city of Ambon and for the highest percentage of malnutrition status in Aru Islands district. While the factors that affect infant mortality, life expectancy, and poor nutritional status in Maluku province using multivariate regression is the percentage of households using latrines with septic tanks $\left(X_{1}\right)$, the percentage of people's active participation in Posyandu $\left(X_{3}\right)$, the percentage the average duration of exclusive breastfeeding infants given $\left(X_{4}\right)$, the percentage of deliveries performed by medical personnel $\left(X_{5}\right)$, the percentage of fully immunized $\left(X_{6}\right)$, the percentage of population density $\left(X_{7}\right)$ and the model can explain the data information of $99.4 \%$
\end{abstract}

Keywords: Infant mortality, life expectancy, multivariate regression model, status of malnutrition 


\section{Pendahuluan}

Kesejahteraan penduduk merupakan aspek penting untuk mengukur kualitas sebuah negara. Kualitas hidup penduduk sangat bergantung dari derajat kesehatan. Indikator utama untuk melihat derajat kesehatan adalah angka kematian bayi, angka harapan hidup, dan status gizi buruk. Oleh karena itu usaha untuk meningkatkan dan memelihara mutu pelayanan kesehatan melalui pemberdayaan sumber daya manusia secara berkelanjutan dan sarana prasarana dalam bidang medis termasuk ketersediaan obat yang dapat dijangkau oleh masyarakat perlu mendapat perhatian utama. Mengingat pentingnya kesehatan, dunia internasional merumuskannya ke dalam Millennium Development Goals (MDGs). MDGs terdiri atas pencapaian pembangunan bidang kesehatan, pendidikan, dan ekonomi. Ketiganya merupakan indikator yang mencerminkan sejauh mana negara mampu memenuhi hak-hak dasar warga negara.

Salah satu usaha pemerintah untuk mewujudkan pembangunan kesehatan melalui pencanangan Program Indonesia Sehat 2010. Tujuan dari Program Indonesia Sehat 2010 adalah terciptanya pembangunan nasional berwawasan kesehatan, kemandirian masyarakat untuk hidup sehat, memelihara, dan meningkatkan pelayanan kesehatan yang bermutu. Visi Indonesia Sehat 2010 yang telah dirumuskan oleh Depatemen Kesehatan menyatakan bahwa, gambaran masyarakat Indonesia dimasa depan yang ingin dicapai melalui pembangunan kesehatan adalah masyarakat, bangsa dan negara yang ditandai oleh penduduknya hidup dalam lingkungan dan dengan perilaku yang sehat, memiliki kemampuan untuk menjangkau pelayanan kesehatan yang bermutu secara adil dan merata, serta memiliki derajat kesehatan yang setinggi-tingginya diseluruh Provinsi Maluku.

Talangko [1] mengungkapkan bahwa faktor-faktor yang mempengaruhi derajat kesehatan adalah adanya jamban dalam rumah, penggunaan air bersih, adanya tempat pengelolaan limbah, perilaku hidup bersih dan sehat, pemberian ASI eksklusif, persalinan dengan tenaga kesehatan, dan tumbuh kembang balita melalui pelayanan kesehatan.

Dalam statistik memberi pengertian bahwa angka kematian bayi, angka harapan hidup dan status gizi buruk (indikator utama) merupakan variabel respon sedangkan faktor-faktor yang mempengaruhi derajat kesehatan merupakan variabel prediktor. Karena terdapat variabel respon lebih dari satu dan antara variabel respon saling memiliki hubungan antara satu dengan yang lain, maka analisis yang dianggap efisien untuk menggambarkan derajat kesehatan di Provinsi Maluku adalah dengan menggunakan analisis regresi multivariat.

Analisis regresi multivariat adalah analisis dimana menjelaskan adanya hubungan atau saling berkorelasi antara lebih dari satu variabel respon dengan satu atau lebih varabel prediktor. Misalkan terdapat variabel respon berjumlah $q$ yaitu $Y_{1}, Y_{2}, \ldots, Y_{q}$ dan $p$ variabel prediktor yaitu $X_{1}, X_{2}, \ldots, X_{p}$ maka model linear multivariat respon ke- $q$ adalah:

$$
\begin{gathered}
Y_{1}=\beta_{01}+\beta_{11} X_{1}+\beta_{p 1} X_{p}+\epsilon_{1} \\
Y_{2}=\beta_{02}+\beta_{12} X_{1}+\beta_{p 2} X_{p}+\epsilon_{2} \\
\vdots \\
Y_{\mathrm{q}}=\beta_{0 \mathrm{q}}+\beta_{1 \mathrm{q}} X_{1}+\beta_{p \mathrm{q}} X_{p}+\epsilon_{\mathrm{q}}
\end{gathered}
$$

Model regresi multivariat yang terdiri dari $q$ model linear secara simultan dapat ditunjukkan bentuk matriks pada persamaan sebagai berikut:

$$
Y_{n x q}=X_{n x(p+1)} \beta_{(p+1) x q}+\varepsilon_{(n x q)} \text { dengan } E\left(\varepsilon_{(i)}\right)=0, \text { dan } \operatorname{Cov}\left(\varepsilon_{(i)}, \varepsilon_{(i)}\right)=\sigma_{i i} I
$$

\section{Metodologi Penelitian}

Tipe penelitian yang digunakan adalah studi kasus yaitu dengan menerapkan metode regresi multivariat berdasarkan faktor-faktor yang mempengaruhi derajat kesehatan di Provinsi Maluku. Data yang digunakan adalah data sekunder yang diperoleh dari Badan Pusat Statistik (BPS) Provinsi Maluku, Profil Kesehatan Provinsi Maluku, serta Survei Sosial Ekonomi Nasional (SUSENAS) tahun 2012. 
Dalam penelitian ini variabel respon yang digunakan adalah $Y_{1}, Y_{2}$, dan $Y_{3}$, berturut-turut menyatakan presentase angka kematian bayi, presentase angka harapan hidup, dan presentase status gizi buruk. Sedangkan variabel prediktor yang digunakan untuk adalah sebagai berikut:

1) Aspek perumahan dan lingkungan

$X_{1}$ : Persentase rumah tangga yang menggunakan jamban dengan tangki septik.

$X_{2}$ : Persentase rumah yang menggunakan air bersih untuk minum/masak (air kemasan, PAM, pompa, sumur terlindung dan mata air terlindung).

2) Aspek perilaku kesehatan

$X_{3}$ : Persentase peran aktif masyarakat dalam posyandu purnama dan mandiri.

$X_{4}$ : Persentase rata-rata lamanya bayi diberi ASI eksklusif .

3) Aspek pelayanan kesehatan

$X_{5}$ : Persentase persalinan yang dilakukan oleh tenaga medis.

$X_{6}$ : Persentase imunisasi lengkap yang mencakup imunisasi BCG, DPT, polio, campak, dan hepatitis.

4) Aspek pelayanan kependudukan

$X_{7}$ : Kepadatan penduduk.

Adapun langkah-langkah yang digunakan untuk menjawab tujuan penelitian yaitu metode analisis yang digunakan adalah statistik deskriptif dengan menggunakan nilai rata-rata, nilai minimum, dan maksimum. Untuk statistik deskriptif secara visual digunakan tabel. Variabel yang digunakan $Y_{1}, Y_{2}, Y_{3}$, dari 11 kabupaten/kota di Provinsi Maluku dan analisis regresi multivariat dengan variabel yang digunakan adalah $Y_{1}, Y_{2}, Y_{3}$, sebagai variabel repon dan $X_{1}, X_{2}, \cdots, X_{7}$, sebagai variabel prediktor.

\section{Hasil dan Pembahasan}

\subsection{Statistika Deskriptif Variabel Respon dan Variabel Prediktor}

Statistik deskriptif variabel respon yang diteliti, bertujuan untuk mengetahui karakteristik dari masingmasing variabel respon. Hasilnya disajikan dalam tabel sebagai berikut.

Tabel 1. Statistik Deskriptif Variabel Respon

\begin{tabular}{|l|c|r|r|r|}
\hline \multicolumn{1}{|c|}{ Variabel Respon } & N & Minimum (dalam \%) & Maksimum (dalam \%) & Mean (dalam \%) \\
\hline Angka Kematian Bayi (AKB) & 11 & 0,00 & 0,10 & 0,0373 \\
\hline Angka Harapan Hidup (AHH) & 11 & 67,00 & 78,97 & 71,2918 \\
\hline Status Gizi Buruk (SGB) & 11 & 0,00 & 0,50 & 0,2618 \\
\hline
\end{tabular}

Statistik Deskriptif variabel prediktor yang diteliti, bertujuan untuk mengetahui karakteristik dari masing-masing variabel prediktor. Hasilnya disajikan dalam Tabel 2.

Tabel 2. Statistik Deskriptif Variabel Prediktor

\begin{tabular}{|l|r|r|r|r|}
\hline Variabel Prediktor & $\mathbf{N}$ & Minimum (dalam \%) & Maksimum (dalam \%) & Mean (dalam \%) \\
\hline Jamban $\left(\mathrm{X}_{1}\right)$ & 11 & 5,76 & 100,00 & 62,5755 \\
\hline Air $\left(\mathrm{X}_{2}\right)$ & 11 & 30,87 & 100,00 & 90,3564 \\
\hline Posyandu $\left(\mathrm{X}_{3}\right)$ & 11 & 3,24 & 77,82 & 41,42 \\
\hline ASI $\left(\mathrm{X}_{4}\right)$ & 11 & 0,00 & 80,15 & 18,5627 \\
\hline Salin Medis $\left(\mathrm{X}_{5}\right)$ & 11 & 60,31 & 88,42 & 76,2482 \\
\hline Imunisasi $\left(\mathrm{X}_{6}\right)$ & 11 & 43,00 & 100,00 & 80,9309 \\
\hline Kep. Penduduk $\left(\mathrm{X}_{7}\right)$ & 11 & 0,77 & 68,24 & 9,6318 \\
\hline
\end{tabular}

Berdasarkan Tabel 1, terlihat bahwa persentase AKB terendah yaitu sebesar 0,00\% (tidak terjadi kematian bayi pada tahun itu) di Kota Ambon, Kabupaten Seram Bagian Timur dan Kota Tual sedangkan yang tertinggi yaitu sebesar 0,10\% yang terjadi di Kabupaten Maluku Tenggara Barat. Untuk persentase AHH terendah yaitu sebesar 67,00\% yang terjadi di Kabupaten Maluku Barat Daya sedangkan yang tertinggi 
yaitu sebesar 78,97\% yang terjadi di Kota Ambon. Untuk persentase SGB terendah yaitu sebesar 0,00\% di Kota Ambon dan yang tertinggi yaitu sebesar 0,50\% yang terjadi di Kabupaten Kepulauan Aru.

Berdasarkan Tabel 2, terlihat bahwa persentase rumah tangga yang menggunakan jamban dengan tangki septik terendah yaitu sebesar 5,76\% di kabupaten Seram Bagian Barat sedangkan yang tertinggi yaitu sebesar $100 \%$ di kabupaten Maluku Tenggara Barat. Untuk persentase penggunaan air bersih yang terendah yaitu sebesar 30,87\% di Kabupaten Seram Bagian Timur sedangkan yang tertinggi yaitu sebesar 100\% di 7 kabupaten/kota yaitu di Ambon, Maluku Tengah, Seram Bagian Barat, Buru, Maluku Tenggara, Maluku Tenggara Barat, dan Maluku Barat Daya. Untuk persentase peran aktif masyarakat dalam posyandu yang terendah yaitu sebesar 3,24\% di kabupaten Seram Bagian Timur sedangkan yang tertinggi yaitu sebesar 77,82\% di Kabupaten Buru. Untuk persentase rata-rata lamanya bayi di beri ASI ekslusif yang terendah yaitu sebesar 0,00\% di Kabupaten Seram Bagian Barat sedangkan yang tertinggi yaitu sebesar 80,15\% di Kabupaten Buru Selatan. Untuk persentase persalinan yang dilakukan oleh tenaga medis yang terendah yaitu sebesar 60,31\% terjadi di Kabupaten Buru Selatan sedangkan yang tertinggi yaitu sebesar 88,42 \% di Kota Ambon. Untuk persentase imunisasi lengkap yang terendah yaitu sebesar 43,00\% di Kabupaten Buru Selatan sedangkan yang tertinggi yaitu sebesar $100 \%$ di Kabupaten Seram Bagian Barat dan Maluku Tenggara Barat. Untuk persentase kepadatan penduduk yang terendah yaitu sebesar 0,77\% di Kabupaten Maluku Tenggara Barat sedangkan yang tertinggi yaitu sebesar 68,24\% di Kota Ambon.

Sebelum dibentuk model regresi multivariat, dilakukan pengujian terlebih dahulu apakah variabel respon terdapat korelasi atau tidak dan berdistribusi normal multivariat. Jika tidak berkorelasi maka analisis dilanjutkan dengan menggunakan regresi univariat, tetapi sebaliknya jika terdapat korelasi antar variabel respon maka dilanjutkan dengan menggunakan regresi multivariat.

Tabel 3. Hubungan antara Variabel Respon

\begin{tabular}{|c|r|r|r|}
\hline Variabel Respon & AKB $\left(\mathbf{Y}_{\mathbf{1}}\right)$ & AHH $\left(\mathbf{Y}_{\mathbf{2}}\right)$ & SGB $\left(\mathbf{Y}_{\mathbf{3}}\right)$ \\
\hline AKB $\left(\mathbf{Y}_{\mathbf{1}}\right)$ & 1 & $-0,536$ & 0,725 \\
\hline AHH $\left(\mathbf{Y}_{\mathbf{2}}\right)$ & $-0,536$ & 1 & $-0,446$ \\
\hline SGB $\left(\mathbf{Y}_{\mathbf{3}}\right)$ & 0,725 & $-0,446$ & 1 \\
\hline
\end{tabular}

Nilai korelasi antara variabel respon terlihat pada Tabel 3 (Output dari SPSS), AKB dan AHH sebesar -0,536 karena nilai negatif maka dapat diartikan bahwa antara angka kematian dan angka harapan hidup memiliki nilai hubungan yang berbanding terbalik artinya jika AHH semakin tinggi maka AKB pun semakin rendah begitupun sebaliknya, untuk nilai korelasi antara AKB dan SGB yaitu 0,725 memiliki nilai hubungan yang berbanding lurus artinya jika angka kematian bayi tinggi maka SGB pun tinggi, dan untuk nilai korelasi AHH dan SGB yaitu -0,446 memiliki nilai hubungan yang berbanding terbalik artinya jika status gizi buruk tinggi maka angka harapan hidup rendah begitupun sebaliknya.

Pengujian yang sesuai untuk mengetahui kebebasan antar variabel respon adalah uji Bartlett Spericity. Hipotesis yang digunakan yaitu:

$\mathrm{H}_{0}$ : Antar variabel respon bersifat independen

$\mathrm{H}_{1}$ : Antar variabel respon bersifat dependen

Statistik uji yang diperoleh yaitu :

$$
\begin{aligned}
\chi_{\text {hit }}^{2} & =-\left\{n-1-\frac{2 q+5}{6}\right\} \ln |\boldsymbol{R}| \\
& =-\left\{11-1-\frac{2 \times 3+5}{6}\right\} \ln \mid\left[\begin{array}{ccc}
1 & -0,536 & 0,725 \\
-0,536 & 1 & -0,446 \\
0,725 & -0,446 & 1
\end{array}\right] \|=8,93
\end{aligned}
$$

Dengan menggunakan $\alpha=0,05$ maka diperoleh $\chi_{0,05 ; 3}^{2}=7,815$. Karena nilai $\chi_{\text {hit }}^{2}=8,93$ lebih besar dari nilai $\chi_{0,05 ; 3}^{2}=7,815$ maka tolak $\mathrm{H}_{0}$ sehingga antar variabel respon bersifat dependen atau antar variabel respon saling berkorelasi. Oleh karena itu dapat digunakan analisis regresi multivariat.

\subsection{Analisis Regresi Multivariat}

Asumsi selanjutnya yang harus dipenuhi dalam analisis regresi multivariat adalah variabel respon berdistribusi normal multivariat. Hipotesis yang digunakan yaitu: 
$H_{0}$ : Variabel respon berdistribusi normal multivariat

$H_{1}$ : Variabel respon tidak berdistribusi normal multivariat

Dengan menggunakan software SPSS diperoleh hasil sebagai berikut:

Tabel 4. Distribusi Normal Multivariat

\begin{tabular}{|l|l|}
\hline \multicolumn{2}{|c|}{$\boldsymbol{d}_{\boldsymbol{i}}^{\mathbf{2}}$} \\
\hline 8,948 & 7,227 \\
\hline 1,503 & 6,543 \\
\hline 7,155 & 4,897 \\
\hline 9,000 & 5,241 \\
\hline 3,853 & 7,241 \\
\hline 8,386 & \\
\hline
\end{tabular}

Berdasarkan Tabel 4 terlihat bahwa dari 11 pengamatan, terdapat 8 pengamatan atau sebesar 72\% nilai $d_{i}^{2}<\chi_{\text {tabel }}^{2}=7,815$. Karena sudah lebih dari 50\% maka terima $\mathrm{H}_{0}$ sehingga data dikatakan berdistribusi normal multivariat.

\subsection{Pemilihan Model Untuk Variabel Prediktor}

Langkah awal untuk pemilihan model dengan menggunakan kriteria AIC adalah membentuk model dengan memasukkan satu persatu variabel prediktor. Hasilnya dapat diperoleh dengan menggunakan bantuan software Eviews. Dari model regresi multivariat didapatkan faktor yang berpengaruh terhadap persentase angka kematian bayi $\left(\mathrm{Y}_{1}\right)$, persentase angka harapan hidup $\left(\mathrm{Y}_{2}\right)$, dan persentase status gizi buruk $\left(\mathrm{Y}_{3}\right)$ dengan menggunakan kriteria AIC diperoleh nilai minimum AIC sebesar -2,292203 yaitu variabel $\mathrm{X}_{1}$, variabel $X_{3}$, variabel $X_{4}$, variabel $X_{5}$, variabel $X_{6}$ dan $X_{7}$ yaitu variabel persentase jamban, presentasi posyandu, presentasi ASI, persentase persalinan oleh tenaga medis, presentasi imunisasi dan presentasi kepadatan penduduk.

\subsection{Estimasi Parameter}

Dengan menggunakan software Eviews, diperoleh hasil estimasi parameter berikut.

Tabel 5. Estimasi Parameter Model

\begin{tabular}{|c|c|r|r|r|r|}
\hline Variabel Respon & Parameter & \multicolumn{1}{|c|}{$\widehat{\boldsymbol{\beta}}$} & Std. Error & \multicolumn{1}{c|}{ t-statistik } & \multicolumn{1}{c|}{ Prob. } \\
\hline \multirow{5}{*}{$\mathrm{Y}_{1}$} & Intercept & 0,131718 & 0,134782 & 0,977269 & 0,3838 \\
\cline { 2 - 6 } & $\mathrm{X}_{1}$ & 0,000232 & 0,000442 & 0,526002 & 0,6267 \\
\cline { 2 - 6 } & $\mathrm{X}_{3}$ & 0,000968 & 0,000573 & 1,691021 & 0,1661 \\
\cline { 2 - 6 } & $\mathrm{X}_{4}$ & 0,000179 & 0,000532 & 0,335394 & 0,7542 \\
\cline { 2 - 6 } & $\mathrm{X}_{5}$ & $-0,003262$ & 0,002323 & $-1,404370$ & 0,2329 \\
\cline { 2 - 6 } & $\mathrm{X}_{6}$ & 0,001281 & 0,000867 & 1,477780 & 0,2135 \\
\cline { 2 - 6 } & $\mathrm{X}_{7}$ & $-0,000763$ & 0,000666 & $-1,145979$ & 0,3157 \\
\hline \multirow{5}{*}{$\mathrm{Y}_{2}$} & Intercept & 55,48472 & 8,625659 & 6,432519 & 0,0030 \\
\cline { 2 - 6 } & $\mathrm{X}_{1}$ & 0,022791 & 0,028274 & 0,806068 & 0,4654 \\
\cline { 2 - 6 } & $\mathrm{X}_{3}$ & $-0,062396$ & 0,036642 & $-1,702829$ & 0,1638 \\
\cline { 2 - 6 } & $\mathrm{X}_{4}$ & 0,034776 & 0,034077 & 1,020494 & 0,3652 \\
\cline { 2 - 6 } & $\mathrm{X}_{5}$ & 0,211831 & 0,148663 & 1,424908 & 0,2273 \\
\cline { 2 - 6 } & $\mathrm{X}_{6}$ & $-0,011854$ & 0,055483 & $-0,213648$ & 0,8413 \\
\cline { 2 - 6 } & $\mathrm{X}_{7}$ & 0,117058 & 0,042606 & 2,747458 & 0,0515 \\
\hline \multirow{5}{*}{$\mathrm{Y}_{3}$} & Intercept & 0,375722 & 0,262329 & 1,432256 & 0,2253 \\
\cline { 2 - 6 } & $\mathrm{X}_{1}$ & 0,001782 & 0,000860 & 2,072482 & 0,1069 \\
\cline { 2 - 6 } & $\mathrm{X}_{3}$ & 0,002977 & 0,001114 & 2,671127 & 0,0557 \\
\cline { 2 - 6 } & $\mathrm{X}_{4}$ & 0,002002 & 0,001036 & 1,931558 & 0,1256 \\
\cline { 2 - 6 } & $\mathrm{X}_{5}$ & $-0,014036$ & 0,004521 & $-3,104467$ & 0,0361 \\
\cline { 2 - 6 } & $\mathrm{X}_{6}$ & 0,009131 & 0,001687 & 5,411221 & 0,0056 \\
\cline { 2 - 6 } & $\mathrm{X}_{7}$ & $-0,005670$ & 0,001296 & 4,376181 & 0,0119 \\
\hline
\end{tabular}




\subsection{Pengujian Signifikansi Model}

\subsubsection{Pengujian Signifikansi Model secara Serentak}

Untuk pengujian signifikansi model secara serentak digunakan uji Wilk’s Lambda. Hipotesis yang digunakan yaitu :

$$
\begin{aligned}
& H_{0}: \beta_{11}=\beta_{13}=\beta_{14}=\cdots=\beta_{35}=\beta_{36}=\beta_{37}=0 \\
& H_{1}: \text { paling sedikit ada satu } \beta_{p q} \neq 0 ; \mathrm{p}=1,3,4,5,6,7 ; \mathrm{q}=1,2,3
\end{aligned}
$$

Dengan menggunakan software SPSS, terlihat bahwa nilai signifikansi Wilk's Lambda yaitu sebesar 0,000. Karena nilai signifikansi kurang dari 0,05 maka tolak Ho sehingga paling sedikit ada satu parameter yang berpengaruh terhadap angka kematian bayi, angka harapan hidup dan status gizi buruk.

\subsubsection{Pengujian Signifikansi Model secara Parsial}

Untuk pengujian signifikansi model secara parsial digunakan uji Wilk's Lambda. Hipotesis yang digunakan yaitu:

1) Variabel persentase penggunaan jamban

$H_{0}: \beta_{11}=\beta_{21}=\beta_{31}=0$

$H_{1}$ : paling sedikit ada satu $\beta_{p q} \neq 0$

Dengan menggunakan software SPSS, diperoleh nilai signifikansinya ( $p$-value) sebesar 0,000 . Karena nilai signifikansi kurang dari 0,05 maka tolak $H_{0}$ sehingga variabel prediktor $X_{1}$ berpengaruh signifikan terhadap variabel respon $Y_{1}, Y_{2}, Y_{3}$.

2) Variabel persentase peran masyarakat ke posyandu

$H_{0}: \beta_{13}=\beta_{23}=\beta_{33}=0$

$H_{1}$ : paling sedikit ada satu $\beta_{p q} \neq 0$

Dengan menggunakan software SPSS, diperoleh nilai signifikansinya ( $p$-value) sebesar 0,000 . Karena nilai signifikansi kurang dari 0,05 maka tolak $H_{0}$ sehingga variabel prediktor $X_{3}$ berpengaruh signifikan terhadap variabel respon $Y_{1}, Y_{2}, Y_{3}$.

3) Variabel persentase pemberian ASI ekslusif untuk bayi

$H_{0}: \beta_{14}=\beta_{24}=\beta_{34}=0$

$H_{1}$ : paling sedikit ada satu $\beta_{p q} \neq 0$

Dengan menggunakan software SPSS, diperoleh nilai signifikansinya ( $p$-value) sebesar 0,000. Karena nilai signifikansi kurang dari 0,05 maka tolak $\mathrm{H}_{0}$ sehingga variabel prediktor $\mathrm{X}_{4}$ berpengaruh signifikan terhadap variabel respon $Y_{1}, Y_{2}, Y_{3}$.

4) Variabel persentase persalinan yang dilakukan oleh tenaga medis

$H_{0}: \beta_{15}=\beta_{25}=\beta_{35}=0$

$H_{1}$ : paling sedikit ada satu $\beta_{p q} \neq 0$

Dengan menggunakan software SPSS, diperoleh nilai signifikansinya ( $p$-value) sebesar 0,000. Karena nilai signifikansi kurang dari 0,05 maka tolak $H_{0}$ sehingga variabel prediktor $X_{5}$ berpengaruh signifikan terhadap variabel respon $Y_{1}, Y_{2}, Y_{3}$.

5) Variabel persentase imunisasi lengkap

$H_{0}: \beta_{16}=\beta_{26}=\beta_{36}=0$

$H_{1}$ : paling sedikit ada satu $\beta_{p q} \neq 0$

Dengan menggunakan software SPSS, diperoleh nilai signifikansinya ( $p$-value) sebesar 0,000. Karena nilai signifikansi kurang dari 0,05 maka tolak $H_{0}$ sehingga variabel prediktor $X_{6}$ berpengaruh signifikan terhadap variabel respon $Y_{1}, Y_{2}, Y_{3}$ 
6) Variabel persentase kepadatan penduduk

$H_{0}: \beta_{17}=\beta_{27}=\beta_{37}=0$

$H_{1}$ : paling sedikit ada satu $\beta_{p q} \neq 0$

Dengan menggunakan software SPSS, diperoleh nilai signifikansinya ( $p$-value) sebesar 0,000. Karena nilai signifikansi kurang dari 0,05 maka tolak $H_{0}$ sehingga variabel prediktor $X_{7}$ berpengaruh signifikan terhadap variabel respon $Y_{1}, Y_{2}, Y_{3}$.

Sehingga model regresi yang diperoleh adalah sebagai berikut:

$$
\begin{aligned}
\mathrm{AKB}= & 0,131718+0,000232 X_{1}+0,000968 X_{3}+0,000179 X_{4}+(-0,003262) X_{5}+0,001281 X_{6}+ \\
& (-0,000763) X_{7}
\end{aligned}
$$

Dari model dapat dijelaskan bahwa :

1) Konstanta sebesar 0,131718 , artinya jika $X_{1}, X_{3}, X_{4}, X_{5}, X_{6}, X_{7}$ nilainya adalah 0 , maka angka kematian bayi sebesar 0,131718\%.

2) Koefesien regresi $X_{1}$ sebesar 0,000232 , artinya jika variabel bebas lainnya tetap dan penggunaan jamban mengalami kenaikan $1 \%$, maka angka kematian bayi mengalami peningkatan sebesar $0,000232 \%$.

3) Koefesien regresi $X_{3}$ sebesar 0,000968, artinya jika variabel bebas lainnya tetap dan peran aktif masyarakat ke posyandu mengalami kenaikan $1 \%$, maka angka kematian bayi mengalami peningkatan sebesar 0,000968\%.

4) Koefesien regresi $X_{4}$ sebesar 0,000179, artinya jika variabel bebas lainnya tetap dan rata-rata lamanya bayi diberi asi eksklusif mengalami kenaikan 1\%, maka angka kematian bayi mengalami peningkatan sebesar 0,000179\%.

5) Koefesien regresi $X_{5}$ sebesar -0,003262, artinya jika variabel bebas lainnya tetap dan persalinan yang dilakukan oleh tenaga medis mengalami kenaikan 1\%, maka angka kematian bayi mengalami penurunan sebesar 0,003262\%.

6) Koefesien regresi $X_{6}$ sebesar 0,001281, artinya jika variabel bebas lainnya tetap dan imunisasi lengkap mengalami kenaikan 1\%, maka angka kematian bayi mengalami peningkatan sebesar 0,001281\%.

7) Koefesien regresi $X_{7}$ sebesar $-0,000763$, artinya jika variabel bebas lainnya tetap dan kepadatan penduduk mengalami kenaikan $1 \%$, maka angka kematian bayi mengalami penurunan sebesar $0,000763 \%$.

$$
\begin{aligned}
\mathrm{AHH}= & 55,48472+0,022791 X_{1}+(-0,062396) X_{3}+0,034776 X_{4}+0,211831 X_{5}+ \\
& (-0,011854) X_{6}+0,117058 X_{7}
\end{aligned}
$$

Dari model dapat dijelaskan bahwa:

1) Konstanta sebesar 55,48472 , artinya jika $X_{1}, X_{3}, X_{4}, X_{5}, X_{6}, X_{7}$ nilainya adalah 0 , maka angka harapan hidup sebesar 55,48472\%.

2) Koefesien regresi $X_{1}$ sebesar 0,022791 , artinya jika variabel bebas lainnya tetap dan penggunaan jamban mengalami kenaikan 1\%, maka angka harapan hidup mengalami peningkatan sebesar 0 , $022791 \%$.

3) Koefesien regresi $X_{3}$ sebesar -0,062396, artinya jika variabel bebas lainnya tetap dan peran aktif masyarakat ke posyandu mengalami kenaikan 1\%, maka angka harapan hidup mengalami penurunan sebesar 0,062396\%.

4) Koefesien regresi $X_{4}$ sebesar 0,034776, artinya jika variabel bebas lainnya tetap dan rata-rata lamanya bayi diberi asi eksklusif mengalami kenaikan 1\%, maka angka harapan hidup mengalami peningkatan sebesar 0,034776\%. 
5) Koefesien regresi $X_{5}$ sebesar 0,211831, artinya jika variabel bebas lainnya tetap dan persalinan yang dilakukan oleh tenaga medis mengalami kenaikan 1\%, maka angka harapan hidup mengalami peningkatan sebesar 0,211831\%.

6) Koefesien regresi $X_{6}$ sebesar $-0,011854$, artinya jika variabel bebas lainnya tetap dan imunisasi lengkap mengalami kenaikan $1 \%$, maka angka harapan hidup mengalami penurunan sebesar $0,011854 \%$.

7) Koefesien regresi $X_{7}$ sebesar 0,117058 , artinya jika variabel bebas lainnya tetap dan kepadatan penduduk mengalami kenaikan 1\%, maka angka harapan hidup mengalami peningkatan sebesar $0,117058 \%$.

$$
\begin{aligned}
\mathrm{SGB}= & 0,375722+0,001782 X_{1}+0,002977 X_{3}+0,002002 X_{4}+(-0,014036) X_{5}+0,009131 X_{6}+ \\
& (-0,005670) X_{7}
\end{aligned}
$$

Dari model dapat dijelaskan bahwa:

1) Konstanta sebesar 0,375722 , artinya jika $X_{1}, X_{3}, X_{4}, X_{5}, X_{6}, X_{7}$ nilainya adalah 0 , maka status gizi buruk sebesar 0,375722\%.

2) Koefesien regresi $X_{1}$ sebesar 0,001782 , artinya jika variabel bebas lainnya tetap dan penggunaan jamban mengalami kenaikan 1\%, maka status gizi buruk mengalami peningkatan sebesar 0,001782\%.

3) Koefesien regresi $X_{3}$ sebesar 0,002977, artinya jika variabel bebas lainnya tetap dan peran aktif masyarakat ke posyandu mengalami kenaikan $1 \%$, maka status gizi buruk mengalami peningkatan sebesar 0,002977\%.

4) Koefesien regresi $X_{4}$ sebesar 0,002002 , artinya jika variabel bebas lainnya tetap dan rata-rata lamanya bayi diberi asi eksklusif mengalami kenaikan 1\%, maka status gizi buruk mengalami peningkatan sebesar 0,002002\%.

5) Koefesien regresi $X_{5}$ sebesar $-0,014036$, artinya jika variabel bebas lainnya tetap dan persalinan yang dilakukan oleh tenaga medis mengalami kenaikan 1\%, maka status gizi buruk mengalami penurunan sebesar 0,014036\%.

6) Koefesien regresi $X_{6}$ sebesar 0,009131, artinya jika variabel bebas lainnya tetap dan imunisasi lengkap mengalami kenaikan 1\%, maka status gizi buruk mengalami peningkatan sebesar 0,009131\%.

7) Koefesien regresi $X_{7}$ sebesar $-0,005670$, artinya jika variabel bebas lainnya tetap dan kepadatan penduduk mengalami kenaikan 1\%, maka status gizi buruk mengalami penurunan sebesar 0, 005670\%.

Berdasarkan model diatas dapat disimpulkan bahwa yang mempengahi angka harapan hidup, angka kematian bayi, dan status gizi buruk adalah persentase rumah tangga yang menggunakan jamban dengan tangki septik $\left(X_{1}\right)$, persentase peran aktif masyarakat dalam posyandu $\left(X_{3}\right)$, persentase rata-rata lamanya bayi di beri ASI ekslusif $\left(X_{4}\right)$, persentase persalinan yang dilakukan oleh tenaga medis $\left(X_{5}\right)$, persentase imunisasi lengkap $\left(X_{6}\right)$, persentase kepadatan penduduk $\left(X_{7}\right)$. Dengan menggunakan software SPSS, diperoleh nilai Wilk's Lambda sebesar 0,006 sehingga nilai $\eta_{\Lambda}^{2}=1-0,006=0,994$. Sehingga besarnya hubungan antara variabel respon dan variabel prediktor yang diperoleh yaitu sebesar 0,994 . Dengan kata lain model dapat menjelaskan informasi data sebesar 99,4\%.

\subsection{Uji Asumsi Residual IIDN}

\subsubsection{Uji Asumsi Residual Identik}

Asumsi selanjutnya yang harus dipenuhi dalam pemodelan secara multivariat adalah matriks varianskovarian residual homogen. Pengujian dilakukan terhadap nilai dari residual dilakukan dengan hipotesis yang digunakan yaitu:

$$
\begin{aligned}
& H_{0}: \sum_{1}=\sum_{2}=\sum_{3}=\sum \\
& H_{1}: \text { Minimal ada satu } \sum_{i} \neq \sum_{j} \text { untuk } i \neq j
\end{aligned}
$$


Dengan menggunakan software SPSS, diperoleh nilai statistik uji Box's-M adalah 2,167 dan nilai $p$-value sebesar 0,354 . Karena nilai $p$-value lebih besar dari 0,05 maka terima $H_{0}$ yang berarti matriks varian-kovarian residual homogen dan dapat disimpulkan bahwa residual identik

\subsubsection{Uji Residual Saling Bebas (Independent)}

Selain asumsi matriks varian-kovarian residual homogen, asumsi residual saling bebas juga harus dipenuhi. Pengujian asumsi ini dilakukan dengan uji Bartlett Spericity.

Hipotesis yang digunakan yaitu :

$H_{0}$ : Residual bersifat independen

$H_{1}$ : Residual bersifat dependen

Dengan menggunakan $\alpha=0,05$ maka diperoleh $\chi_{0,05 ; 3}^{2}=7,815$. Karena nilai $\chi_{\text {hit }}^{2} 4,217$ lebih kecil dari nilai $\chi_{0,05 ; 3}^{2}=7,815$ maka terima $H_{0}$ sehingga residual bersifat independent (saling bebas)

\subsubsection{Uji Asumsi Residual Berdistribusi Normal}

Selanjutnya asumsi yang harus dipenuhi adalah residual berdistribusi normal multivariat. Hipotesis yang digunakan yaitu :

$H_{0}$ : Residual berdistribusi normal multivariat

$H_{1}$ : Residual tidak berdistribusi normal multivariat

Dengan menggunakan sotware SPSS diperoleh hasil sebagai berikut.

Tabel 6. Distribusi Normal Multivariat untuk Residual

\begin{tabular}{|c|c|}
\hline \multicolumn{2}{|c|}{$\boldsymbol{d}_{\boldsymbol{i}}^{\mathbf{2}}$} \\
\hline 8,887 & 6,416 \\
\hline 1,434 & 6,365 \\
\hline 4,551 & 4,751 \\
\hline 3,463 & 5,241 \\
\hline 3,532 & 6,996 \\
\hline 8,357 & \\
\hline
\end{tabular}

Berdasarkan Tabel 6, terlihat bahwa dari 11 pengamatan, terdapat 9 pengamatan atau sebesar 81\% nilai $d_{i}^{2}<\chi_{\text {tabel }}^{2}=7,815$. Karena sudah lebih dari $50 \%$ maka terima $H_{0}$ sehingga residual dikatakan berdistribusi normal multivariat.

\section{Kesimpulan}

Berdasarkan hasil analisis data dan pembahasan maka dapat diambil kesimpulan sebagai berikut:

1) Persentase Angka Kematian Bayi terendah yaitu sebesar 0,00\% (tidak terjadi kematian bayi pada tahun itu) terjadi di kota Ambon, Kabupaten Seram Bagian Timur dan Kota Tual dan tertinggi yaitu sebesar 0,10\% terjadi di kabupaten Maluku Tenggara Barat. Untuk persentase angka harapan hidup terendah yaitu sebesar 67,00\% terjadi di Kabupaten Maluku Barat Daya dan tertinggi yaitu sebesar 78,97\% terjadi di Kota Ambon. Sedangkan, untuk persentase Status Gizi Buruk terendah yaitu sebesar 0,00\% terjadi di kota Ambon dan tertinggi yaitu sebesar 0,50\% yang terjadi di Kabupaten Kepulauan Aru.

2) Faktor-faktor yang mempengaruhi angka kematian bayi, Angka Harapan Hidup dan Status Gizi Buruk adalah persentase rumah tangga yang menggunakan jamban dengan tangki septik $\left(\mathrm{X}_{1}\right)$, persentase peran aktif masyarakat dalam posyandu $\left(\mathrm{X}_{3}\right)$, persentase rata-rata lamanya bayi diberi ASI ekslusif $\left(\mathrm{X}_{4}\right)$, persentase persalinan yang dilakukan oleh tenaga medis $\left(\mathrm{X}_{5}\right)$, persentase imunisasi lengkap $\left(\mathrm{X}_{6}\right)$, persentase kepadatan penduduk $\left(\mathrm{X}_{7}\right)$. Dengan model sebagai berikut:

$$
\begin{gathered}
A K B=0,131718+0,000232 \mathrm{X}_{1}+0,000968 \mathrm{X}_{3}+0,000179 \mathrm{X}_{4}+(-0,003262) \mathrm{X}_{5} \\
+0,001281 \mathrm{X}_{6}+(-0,000763) \mathrm{X}_{7}
\end{gathered}
$$




$$
\begin{gathered}
A H H=55,48472+0,022791 \mathrm{X}_{1}+(-0,062396) \mathrm{X}_{3}+0,034776 \mathrm{X}_{4}+0,211831 \mathrm{X}_{5} \\
+(-0,011854) \mathrm{X}_{6}+0,117058 \mathrm{X}_{7} \\
\begin{array}{c}
S G B=0,375722+0,001782 \mathrm{X}_{1}+0,002977 \mathrm{X}_{3}+0,002002 \mathrm{X}_{4}+(-0,014036) \mathrm{X}_{5} 0,009131 \mathrm{X}_{6} \\
+(-0,005670) \mathrm{X}_{7}
\end{array}
\end{gathered}
$$

dan besarnya hubungan antara variabel respon dan variabel prediktor diperoleh nilai $\eta_{\Lambda}^{2}=1-0,006=0,994$. Hal ini berarti model dapat menjelaskan informasi data sebesar 99,4\%.

Berdasarkan hasil penelitian, penulis menyarankan kepada pemerintah untuk lebih meningkatkan perhatian dalam bidang kesehatan terkhusus dalam hal penyediaan jamban dengan tangki septik, peran aktif penduduk ke posyandu, pemberian ASI ekslusif untuk bayi, persalinan yang sebaiknya dilakukan oleh tenaga medis, imunisasi lengkap, serta kepadatan penduduk supaya menekan angka kematian bayi dan status gizi buruk serta angka harapan hidup semakin tinggi, kepada penelitian selanjutnya disarankan adanya peningkatan penelitian yang lebih dalam dan lebih spesifik kepada hal-hal yang menyangkut kesejahteraan penduduk dengan adanya penambahan faktor-faktor lain yang berkaitan langsung maupun tidak langsung dengan kesehatan di Provinsi Maluku.

\section{Daftar Pustaka}

[1] L. Talangko, Pemodelan Persamaan Struktural dengan Maximum Likelihood dan Bootstrap pada derajat Kesehatan di Provinsi Sulawesi Selatan, 2009.

[2] H. Sasrawan, "Kehidupan Awal Masyarakat Indonesia,” 2 Januari 2013. [Online]. Available: http://hedisasrawan.blogspot.co.id/2013/01/kehidupan-awal-masyarakat-indonesia.html?m=1. [Accessed 5 November 2015].

[3] Apriadji, Gizi Keluarga, Jakarta: Penebar Swadaya, 1986.

[4] Badan Pusat Statistik. Maluku, “Analisa Penyusunan Kinerja Makro Ekonomi dan Sosial Maluku Tahun 2012,” Badan Pusat Statistik Provinsi Maluku, Ambon, 2012.

[5] Badan Pusat Statistik Maluku, “Laporan Eksekutif Kesehatan Provinsi Maluku 2012,” Badan Pusat Statistik Provinsi Maluku, Ambon, 2012.

[6] Departemen Kesehatan RI, "Indikator Sehat Indonesia 2010 dan Pedoman Penetapan Indikator Provinsi Sehat dan Kabupaten/Kota Sehat, Keputusan Menteri Kesehatan No. 1202/Menkes/SK/VII/2003,” Departemen Kesehatan RI, Jakarta, 2003.

[7] N. Draper and H. Smith, “Analisis Regresi Terapan,” Gramedia, Jakarta, 1992.

[8] D. Gurajati, Dasar-Dasar Ekonometrika, Jakarta: Erlangga, 2006.

[9] I. Hasan, Pokok-pokok Materi Statistik 2 (Statistika Inferensial), Jakarta: Bumi Aksara, 2010.

[10] R. A. Johnson and D. Wichern, Applied Multivariat Statistical Analysis, New Jersey: Pretice Hall, 2007.

[11] D. F. Morrison, Multivariat Statistical Methods, Fourth Edition, Pennsylvania: The Wharton School Unoversity of Pennsylvania, 2005.

[12] D. Priyatno, Analisis Korelasi, Regresi, dan Multivariat dengan SPSS, Yogyakarta: Gava Media, 2013.

[13] A. R. Rencher, Methods of Multivariat Analysis, Second Edition, New York: John Wiley \& Sons, Inc., 2002.

[14] R. E. Walpole and R. H. Myers, Ilmu Peluang dan Statistika untuk Insinyur dan Ilmuwan, Edisi Keempat, Bandung: Penerbit ITB, 1995. 